\title{
Dermacoccus abyssi sp. nov., a piezotolerant actinomycete isolated from the Mariana Trench
}

Correspondence

Michael Goodfellow

m.goodfellow@ncl.ac.uk

\author{
Wasu Pathom-aree, ${ }^{1} \dagger$ Yuichi Nogi, ${ }^{2}$ lain C. Sutcliffe, ${ }^{3}$ Alan C. Ward, ${ }^{1}$ \\ Koki Horikoshi, ${ }^{2}$ Alan T. Bull ${ }^{4}$ and Michael Goodfellow ${ }^{1}$ \\ ${ }^{1}$ Division of Biology, King George VI Building, University of Newcastle, Newcastle upon Tyne \\ NE1 7RU, UK \\ ${ }^{2}$ Extremobiosphere Research Center, Japan Agency for Marine-Earth Science and Technology \\ (JAMSTEC), 2-15 Natsushima-cho, Yokosuka 237-0061, Japan
}

${ }^{3}$ School of Applied Sciences, Northumbria University, Newcastle upon Tyne NE1 8ST, UK

${ }^{4}$ Department of Biosciences, University of Kent, Canterbury, Kent CT2 7NJ, UK

\begin{abstract}
The taxonomic status of an actinobacterial strain isolated from Mariana Trench sediment was determined using a polyphasic taxonomic approach. The strain, isolate MT1. ${ }^{\top}$, formed a distinct clade in the Micrococcineae 16S rRNA gene tree together with Dermacoccus nishinomiyaensis DSM $20448^{\top}$. The organism had chemical and phenotypic properties consistent with its classification in the genus Dermacoccus and could be distinguished from $D$. nishinomiyaensis DSM $20448^{\top}$ using DNA-DNA relatedness and phenotypic data. The $\mathrm{G}+\mathrm{C}$ content of the DNA of isolate MT1.1 ${ }^{\top}$ was $65.2 \mathrm{~mol} \%$. It is evident that the organism merits recognition as a novel species in the genus Dermacoccus. The name proposed for this taxon is Dermacoccus abyssi sp. nov.; the type strain is MT1.1 $1^{\top}\left(=\mathrm{DSM} 17573^{\top}=\mathrm{NCIMB} 14084^{\top}\right)$. The organism grows well at $40 \mathrm{MPa}$ and hence is piezotolerant.
\end{abstract}

The monospecific genus Dermacoccus was proposed by Stackebrandt et al. (1995) to accommodate actinomycetes that had been isolated from human skin and water and previously classified as Micrococcus nishinomiyaensis Oda 1935 emend. Kocur et al. 1975. The genus belongs to the family Dermacoccaceae Stackebrandt and Schumann 2000, as do the genera Demetria Groth et al. 1997 and Kytococcus Stackebrandt et al. 1995; members of this family are usually associated with terrestrial habitats, notably cured meat products, skin and soil (De la Rosa et al., 1990; Cordero \& Zumalacárregui, 2000; Papamanoli et al., 2002).

The present study was designed to establish the taxonomic status of an actinobacterial strain, isolate MT1.1 ${ }^{\mathrm{T}}$, recovered from sediment collected from the Challenger Deep in the Mariana Trench and considered to be closely related to the genus Dermacoccus using 16S rRNA gene sequence data (Pathom-aree et al., 2006). The strain was the subject of a polyphasic taxonomic study, which showed that it merited recognition within a novel species of Dermacoccus.

Sediment was taken from the Mariana Trench (Challenger Deep; $11^{\circ} 19 \cdot 911^{\prime} \mathrm{N} 142^{\circ} 12 \cdot 372^{\prime} \mathrm{E}$ ) at a depth of $10898 \mathrm{~m}$

tPresent address: Department of Biology, Faculty of Science, Chiang Mai University, Chiang Mai 50200, Thailand.

The GenBank/EMBL/DDBJ accession number for the $16 \mathrm{~S}$ rRNA gene sequence of Dermacoccus abyssi MT1.1 ${ }^{\top}$ is AY894323. using sterilized mud samplers and the remotely operated submersible Kaiko (Kato et al., 1997). The sample (2 ml), which was collected on 21 May 1998 during dive number 74, was transported to the UK in an insulated container at $4{ }^{\circ} \mathrm{C}$ and then stored at $-20^{\circ} \mathrm{C}$. Strain MT1.1 $1^{\mathrm{T}}$ was isolated from a suspension of the sediment sample used to inoculate a raffinose-histidine agar plate (Vickers et al., 1984) supplemented with cycloheximide and nystatin. It was maintained on glucose-yeast extract agar plates (Gordon \& Mihm, 1962) at room temperature and as glycerol suspensions $(20 \%, \mathrm{v} / \mathrm{v})$ at $-20{ }^{\circ} \mathrm{C}$.

Isolation of chromosomal DNA, PCR amplification and direct sequencing of the purified products of strain MT1.1 ${ }^{\mathrm{T}}$ were carried out as described previously (Kim et al., 2000). The amplified 16S rRNA gene sequence (1443 nt) was aligned manually with corresponding sequences of representatives of genera classified in the suborder Micrococcineae that had been retrieved from DDBJ/EMBL/GenBank using the program PHYDIT (available at http://plaza.snu.ac.kr/ $\sim$ jchun/phydit/). Phylogenetic trees were inferred using the least-squares (Fitch \& Margoliash, 1967), maximumlikelihood (Felsenstein, 1981), maximum-parsimony (Kluge \& Farris, 1969) and neighbour-joining (Saitou \& Nei, 1987) tree-making algorithms from the PHYLIP suite of programs (Felsenstein, 1993). Evolutionary distance matrices for the least-squares and neighbour-joining methods were generated after Jukes \& Cantor (1969). Stability of the resultant 
tree topologies was evaluated by bootstrap analysis (Felsenstein, 1985), based on the neighbour-joining dataset, of 1000 resamplings using the SEQBOOT and CONSENSE options from the PHYLIP package. The $\mathrm{G}+\mathrm{C}$ content of the DNA of isolate MT1.1 ${ }^{\mathrm{T}}$ was determined by reversed-phase HPLC (Tamaoka \& Komagata, 1984).

It is evident from Fig. 1 that isolate MT1 $11^{\mathrm{T}}$ formed a distinct clade in the Micrococcineae 16S rRNA gene tree together with Dermacoccus nishinomiyaensis DSM $20448^{\mathrm{T}}$; this association was supported by all of the tree-making algorithms and by a $100 \%$ bootstrap value in the neighbour-joining analysis. The two organisms shared $98.5 \%$ 16S rRNA gene sequence similarity, a value that corresponds to $21 \mathrm{nt}$ differences at the 1443 locations available for alignment. The DNA G + C content of isolate MT1.1 ${ }^{\mathrm{T}}$ was $65 \cdot 2 \mathrm{~mol} \%$.

Isolate MT1.1 $1^{\mathrm{T}}$ was examined for key chemical markers to determine whether it had a chemotaxonomic profile consistent with its classification in the genus Dermacoccus. The required biomass, derived from a 7-day-old glucose-yeast extract broth (Gordon \& Mihm, 1962) shake culture grown at $28^{\circ} \mathrm{C}$, was harvested by centrifugation, washed twice with sterile distilled water and freeze-dried. Standard methods were used for the extraction and analysis of fatty acids (Sutcliffe, 2000), mycolic acids (Hamid et al., 1993), isoprenoid quinones (Collins, 1994), muramic acid type (Uchida et al., 1999) and polar lipids (Minnikin et al., 1984). The peptidoglycan structure of the isolate was determined by the DSMZ identification service using established procedures (Schleifer \& Kandler, 1972; Schleifer, 1985; MacKenzie, 1987).

Strain MT1.1 ${ }^{\mathrm{T}}$ had chemical properties consistent with its assignment to the genus Dermacoccus Stackebrandt et al. 1995. It contains $N$-acetylated muramic acid, diphosphatidylglycerol, phosphatidylglycerol and phosphatidylinositol as major polar lipids (phospholipid type I sensu Lechevalier et al., 1977) and dihydrogenated menaquinones with eight isoprene units as the predominant isoprenologue, but lacks mycolic acids. One- and two-dimensional TLC of the total hydrolysate of the peptidoglycan $\left(4 \mathrm{M} \mathrm{HCl}, 16 \mathrm{~h}\right.$ at $\left.100{ }^{\circ} \mathrm{C}\right)$ revealed the presence of the amino acids alanine, glutamic acid, lysine and serine. Following derivatization, the molar amino acid ratios as determined by GC were $2 \cdot 0$ Ala, $0.8 \mathrm{Ser}$, $2 \cdot 3$ Glu and 1.0 Lys; traces of hydrolytically stable peptide were also found (Lys-Ser). Partial hydrolysis $(4 \mathrm{M} \mathrm{HCl}$, $45 \mathrm{~min}$ at $100^{\circ} \mathrm{C}$ ) and two-dimensional TLC showed the presence of several peptides: L-Ala-D-Glu, D-Ala-D-Glu, L-Lys-L-Ser and D-Ala-L-Lys-L-Ser. Denitrophenylation indicated that the glutamic acid was derived from the $\mathrm{N}$ terminus of the interpeptide bridge. It is clear from these data that the strain has an A4 $\alpha$ peptidoglycan type sensu Schleifer \& Kandler (1972).

The fatty acids of the organism were rich in the branchedchain components 13-methyltetradecanoic (iso-C15:0; $7 \%$ of total), 14-methylpentadecanoic (iso-C16:0;35\% of total), 15-methylhexadecanoic (iso-C17:0;10\% of total) and 14-methylhexadecanoic acids (anteiso-C17:0;18\% of total); the unsaturated components heptadecenoic acid (C17: $1 ; 7 \%$ of total) and octadecenoic acid (C18:1; $7 \%$ of total) were also present. Minor fatty acids detected (cumulatively $13 \%$ of total) included iso-C14:0, C16:0, $\mathrm{C} 17: 0$ and $\mathrm{C} 18: 0$ (each $\leqslant 4 \%$ of total). A very similar fatty acid profile was obtained for Dermacoccus nishinomiyaensis DSM $20448^{\mathrm{T}}$ (data not shown).

Dermacoccus nishinomiyaensis and members of the genus Kytococcus have been reported to contain significant quantities of unsaturated branched-chain fatty acids, notably 15methylhexadecenoic acid (iso-C17:1, 11-33\% of total; Stackebrandt et al., 1995; Becker et al., 2002). Strain MT1.1 ${ }^{\mathrm{T}}$ contained small quantities ( $<5 \%$ of total) of unidentified fatty acids that may be unsaturated branched-chain fatty acids, but a significant peak attributable to iso-C17:1 was

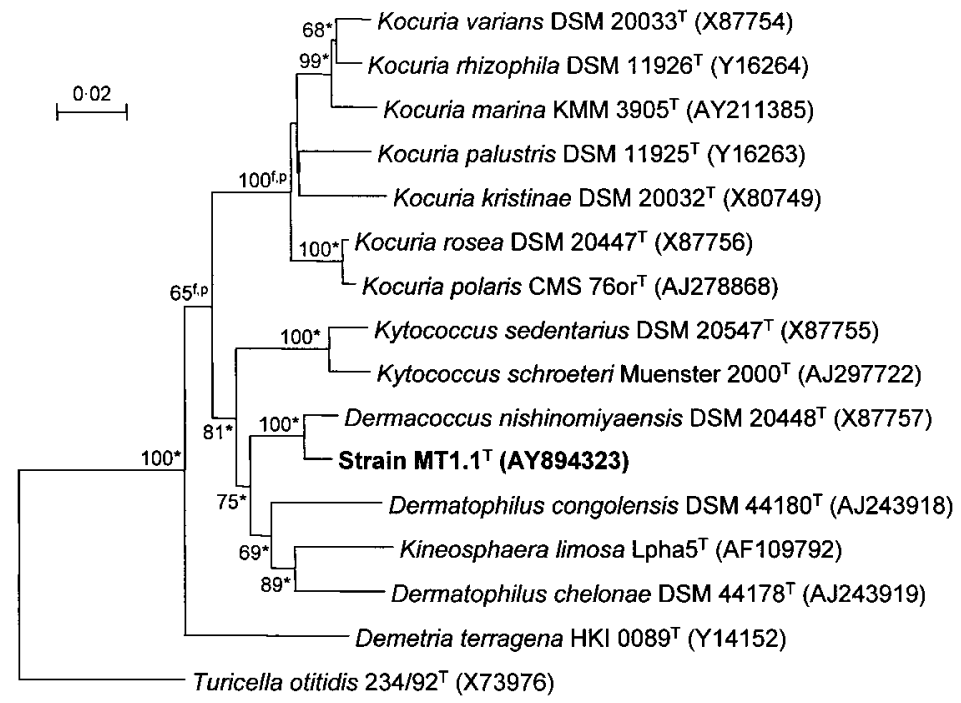

Fig. 1. Neighbour-joining tree (Saitou \& Nei, 1987) based on almost complete $16 \mathrm{~S}$ rRNA gene sequences showing relationships between isolate MT1.1 $1^{\top}$ and representatives of the suborder Micrococcineae. Asterisks indicate phyletic lines that were recovered using the least-squares (Fitch \& Margoliash, 1967), maximum-likelihood (Felsenstein, 1981) and maximum-parsimony (Kluge \& Farris, 1969) tree-making algorithms; $f$ and $p$ indicate branches formed using the least-squares and maximum-parsimony methods, respectively. Numbers at nodes show percentages of bootstrap support based on a neighbour-joining analysis of 1000 resampled datasets; only values above $50 \%$ are given. Bar, 0.02 substitutions per nucleotide position. 
not identified in either strain MT1.1 $1^{\mathrm{T}}$ or Dermacoccus nishinomiyaensis DSM $20448^{\mathrm{T}}$. Production of significant quantities of unsaturated branched-chain fatty acids may thus be variable with respect to growth conditions. It is also interesting that Demetria terragena DSM $11295^{\mathrm{T}}$, a representative of the third genus currently classified in the family Dermacoccaceae (Stackebrandt \& Schumann, 2000), was reported to contain branched-chain, though not unsaturated, fatty acids (Groth et al., 1997). Moreover, it is clearly of note that representatives of all of the genera presently grouped in the family Dermacoccaceae synthesize significant quantities of branched-chain fatty acids, whereas these components are absent from members of the closely related family Dermatophilaceae (McNabb et al., 1997; Liu et al., 2002; Stackebrandt, 2003), although there have been reports of branched-chain fatty acids in some strains of Dermatophilus congolensis (Hasegawa et al., 1979; Dusch et al., 1994). The families Dermacoccaceae and Dermatophilaceae were defined on the basis of signature nucleotides in their $16 \mathrm{~S}$ rRNA gene sequences (Stackebrandt \& Schumann, 2000); hence, the fatty acid data provide additional evidence for the distinction of these taxa.

DNA-DNA hybridization experiments were carried out between isolate MT1. $1^{\mathrm{T}}$ and Dermacoccus nishinomiyaensis DSM $20448^{\mathrm{T}}$ using the microplate method, as described by Ezaki et al. (1989); the mean percentage DNA-DNA relatedness value was calculated from three hybridization experiments. The mean DNA-DNA relatedness found between the two organisms was $15 \pm 0 \cdot 6 \%$, a value well below the $70 \%$ cut-off point recommended for the assignment of bacterial strains to the same genomic species (Wayne et al., 1987).

Biochemical and physiological characteristics of strain MT1.1 $1^{\mathrm{T}}$ were examined using methods described by Kloos et al. (1974). It is clear from Table 1 that strain MT1.1 ${ }^{\mathrm{T}}$ can be separated from the type strain of Dermacoccus nishinomiyaensis using a combination of phenotypic properties.

Strain $\mathrm{MT} 1.1^{\mathrm{T}}$ and Dermacoccus nishinomiyaensis DSM $20448^{\mathrm{T}}$ were examined for growth at $40 \mathrm{MPa}$, according to Heald et al. (2001), in hydraulically pressurized vessels (bomb no. 4740; Parr Instruments) constructed from an Inconel 625 high-strength nickel-chromium alloy. Growth was measured as the change in total viable counts on glucose-yeast extract agar following incubation at $30^{\circ} \mathrm{C}$ for 4 days; control cultures of the organisms were incubated at atmospheric pressure. The isolate grew well at $40 \mathrm{MPa}$, giving a viable count of $3 \cdot 6 \pm 0.4 \times 10^{6}$ c.f.u. $\mathrm{ml}^{-1}$, an increase of $60 \%$ over that of the control culture $(1 \cdot 46 \pm$ $0 \cdot 7 \times 10^{6}$ c.f.u. $\mathrm{ml}^{-1}$ ) and can thereby be considered to be a piezotolerant actinomycete. In contrast, Dermacoccus nishinomiyaensis DSM $20448^{\mathrm{T}}$ showed a decrease in viable counts from $1 \cdot 27 \pm 0 \cdot 4 \times 10^{6}$ c.f.u. $\mathrm{ml}^{-1}$ at atmospheric pressure to $8 \cdot 1 \pm 1 \cdot 3 \times 10^{5}$ c.f.u. $\mathrm{ml}^{-1}$ at $40 \mathrm{MPa}$.

It can be concluded from the genotypic and phenotypic data that isolate MT1.1 ${ }^{\mathrm{T}}$ represents a novel species within the
Table 1. Phenotypic properties that differentiate isolate MT1. ${ }^{\top}$ from Dermacoccus nishinomiyaensis DSM $20448^{\top}$

+ , Positive, - , negative. Neither strain formed acid from adonitol, $\mathrm{D}(+)$-arabinose, $\mathrm{D}(+)$-arabitol, $\mathrm{L}(-)$-arabitol, $\mathrm{D}(+)$-cellobiose, dextran, dextrin, meso-erythritol, $\mathrm{D}(+)$-fructose, $\mathrm{D}(+)$-galactose, $\mathrm{D}(+)$-glucose, $\mathrm{D}(+)$-glycerol, glycogen, myo-inositol, inulin, $\mathrm{D}(+)$-maltose, $\mathrm{D}(+)$-mannitol, $\mathrm{D}(+)$-mannose, $\mathrm{D}(+)$-melezitose, $\mathrm{D}(+)$-melibiose, $\mathrm{D}(+)$-raffinose, $\mathrm{D}(+)$-rhamnose, $\mathrm{D}(+)$-salicin, sucrose, $\mathrm{D}(+)$-trehalose, $\mathrm{D}(+)$-sorbitol, $\mathrm{L}(+)$-sorbose, xylitol or $\mathrm{D}(+)$-xylose.

\begin{tabular}{|lcc|}
\hline Character & MT1.1 $^{\mathbf{T}}$ & DSM $\mathbf{2 0 4 4 8}^{\mathbf{T}}$ \\
\hline Degradation of: & & - \\
$\quad$ Aesculin & + & - \\
Arbutin & + & + \\
Gelatin & - & - \\
Guanine & + & - \\
Tween 80 & + & - \\
Growth on $10 \% \mathrm{NaCl}$ & + & - \\
Growth at $10{ }^{\circ} \mathrm{C}$ & + & - \\
Growth at $40 \mathrm{MPa}$ & + & \\
\hline
\end{tabular}

genus Dermacoccus. The name proposed for this taxon is Dermacoccus abyssi sp. nov.

\section{Description of Dermacoccus abyssi sp. nov.}

Dermacoccus abyssi (a.bys'si. N.L. gen. n. abyssi of an abyss).

Non-acid-alcohol-fast, non-motile actinomycete. Forms coccoid cells (diameter $0 \cdot 8-1 \cdot 5 \mu \mathrm{m}$ ) that occur in irregular clusters. Cream to pale-yellow, circular, entire, convex, smooth, glistening colonies are formed on glucose-yeast extract agar after 5 days at $28^{\circ} \mathrm{C}$. Grows well on tryptic soy agar, but poorly on inorganic nitrogen agar. Growth occurs between 10 and $37^{\circ} \mathrm{C}$, with optimum growth around $28^{\circ} \mathrm{C}$. Casein, cellulose, hypoxanthine, starch and uric acid are degraded. Growth occurs in the presence of $7 \cdot 5 \% \mathrm{NaCl}$. Additional phenotypic properties are shown in Table 1. Grows well in glucose-yeast extract broth at $40 \mathrm{MPa}$.

The type and only strain is isolate MT1.1 ${ }^{\mathrm{T}}$ (=DSM $17573^{\mathrm{T}}=$ NCIMB $\left.14084^{\mathrm{T}}\right)$, recovered from sediment collected from the Challenger Deep of the Mariana Trench at a depth of $10898 \mathrm{~m}$. The DNA G $+\mathrm{C}$ content of the type strain is $65 \cdot 2 \mathrm{~mol} \%$.

\section{Acknowledgements}

W. P. is grateful to the DPST program and the Royal Thai Government for financial support. We thank the Kaiko operation team and the crew of MS Yokosuka for collecting sediment samples and to Dr Jean Euzéby for his help in naming the organism. This work was supported by the UK Natural Environment Research Council (grants NER/T/S/2000/ 00614 and NER/T/S/2000/00616). A. T. B. thanks the Leverhulme Trust for the award of an Emeritus Fellowship. 


\section{References}

Becker, K., Schumann, P., Wullenweber, J., Schulte, M., Weil, H. P., Stackebrandt, E., Peters, G. \& von Eiff, C. (2002). Kytococcus schroeteri sp. nov., a novel Gram-positive actinobacterium isolated from a human clinical source. Int J Syst Evol Microbiol 52, 1609-1614.

Collins, M. D. (1994). Isoprenoid quinones. In Chemical Methods in Prokaryotic Systematics, pp. 265-309. Edited by M. Goodfellow \& A. G. O'Donnell. Chichester: Wiley.

Cordero, M. R. \& Zumalacárregui, J. M. (2000). Characterization of Micrococcaceae isolated from salt used for Spanish dry-cured ham. Lett Appl Microbiol 31, 303-306.

De la Rosa, M. C., Mohino, M. R., Mohino, M. \& Mosso, M. A. (1990). Characteristics of micrococci and staphylococci isolated from semipreserved meat products. Food Microbiol 7, 207-215.

Dusch, H., Huszar, A., Nicolet, J., von Graevenitz, A. \& Collins, M. D. (1994). Characterization of an unusual human isolate of Dermatophilus congolensis. Med Microbiol Lett 3, 36-41.

Ezaki, T., Hashimoto, Y. \& Yabuuchi, E. (1989). Fluorometric deoxyribonucleic acid-deoxyribonucleic acid hybridization in microdilution wells as an alternative to membrane filter hybridization in which radioisotopes are used to determine genetic relatedness among bacterial strains. Int J Syst Bacteriol 39, 224-229.

Felsenstein, J. (1981). Evolutionary trees from DNA sequences: a maximum likelihood approach. J Mol Evol 17, 368-376.

Felsenstein, J. (1985). Confidence limits on phylogenies: an approach using the bootstrap. Evolution 39, 783-791.

Felsenstein, J. (1993). PHYLIP (phylogeny inference package), version 3.5c. Distributed by the author. Department of Genome Sciences, University of Washington, Seattle, USA.

Fitch, W. M. \& Margoliash, E. (1967). Construction of phylogenetic trees: a method based on mutation distances as estimated from cytochrome $c$ sequences is of general applicability. Science 155, 279-284.

Gordon, R. E. \& Mihm, J. M. (1962). Identification of Nocardia caviae (Erikson) nov. comb. Ann N Y Acad Sci 98, 628-636.

Groth, I., Schumann, P., Rainey, F. A., Martin, K., Schuetze, B. \& Augsten, K. (1997). Demetria terragena gen. nov., sp. nov., a new genus of actinomycetes isolated from compost soil. Int J Syst Bacteriol 47, 1129-1133.

Hamid, M. E., Minnikin, D. E., Goodfellow, M. \& Ridell, M. (1993). Thin-layer chromatographic analysis of glycolipids and mycolic acids from Mycobacterium farcinogenes, Mycobacterium senegalense and related taxa. Zentralbl Bakteriol 279, 354-367.

Hasegawa, T., Lechevalier, M. P. \& Lechevalier, H. A. (1979). Phospholipid composition of motile actinomycetes. J Gen Appl Microbiol 25, 209-213.

Heald, S. C., Brandão, P. F. B., Hardicre, R. \& Bull, A. T. (2001). Physiology, biochemistry and taxonomy of deep-sea nitrile metabolising Rhodococcus strains. Antonie van Leeuwenhoek 80, 169-183.

Jukes, T. H. \& Cantor, C. R. (1969). Evolution of protein molecules. In Mammalian Protein Metabolism, vol. 3, pp. 21-132. Edited by H. N. Munro. New York: Academic Press.

Kato, C., Li, L., Tamaoka, J. \& Horikoshi, K. (1997). Molecular analyses of the sediment of the 11,000-m deep Mariana Trench. Extremophiles 1, 117-123.

Kim, S. B., Brown, R., Oldfield, C., Gilbert, S. C., Iliarionov, S. \& Goodfellow, M. (2000). Gordonia amicalis sp. nov., a novel dibenzothiophene-desulphurizing actinomycete. Int J Syst Evol Microbiol 50, 2031-2036.

Kloos, W. E., Tornabene, T. G. \& Schleifer, K. H. (1974). Isolation and characterization of micrococci from human skin, including two new species: Micrococcus lylae and Micrococcus kristinae. Int J Syst Bacteriol 24, 79-101.

Kluge, A. G. \& Farris, F. S. (1969). Quantitative phyletics and the evolution of anurans. Syst Zool 18, 1-32.

Kocur, M., Schleifer, K. H. \& Kloos, W. E. (1975). Taxonomic status of Micrococcus nishinomiyaensis Oda 1935. Int J Syst Bacteriol 25, 290-293.

Lechevalier, M. P., De Bièvre, C. \& Lechevalier, H. A. (1977). Chemotaxonomy of aerobic actinomycetes: phospholipid composition. Biochem Syst Ecol 5, 249-260.

Liu, W.-T., Hanada, S., Marsh, T. L., Kamagata, Y. \& Nakamura, K. (2002). Kineosphaera limosa gen. nov., sp. nov., a novel Gram-positive polyhydroxyalkanoate-accumulating coccus isolated from activated sludge. Int J Syst Evol Microbiol 52, 1845-1849.

MacKenzie, S. L. (1987). Gas chromatographic analysis of amino acids as the N-heptafluorobutyryl isobutyl esters. J Assoc Off Anal Chem 70, 151-160.

McNabb, A., Shuttleworth, R., Behme, R. \& Colby, W. D. (1997). Fatty acid characterization of rapidly growing pathogenic aerobic actinomycetes as a means of identification. J Clin Microbiol 35, 1361-1368.

Minnikin, D. E., O’Donnell, A. G., Goodfellow, M., Alderson, G., Athalye, M., Schaal, K. \& Parlett, J. H. (1984). An integrated procedure for the extraction of bacterial isoprenoid quinones and polar lipids. J Microbiol Methods 2, 233-241.

Oda, M. (1935). Bacteriological studies on waters used for brewing saké (part 6). I. Bacteriological studies on "miyamizu" (8) and (9). Micrococcus and Actinomyces isolated from "miyamizu". Jozogaku Zasshi 13, 1202-1228 (in Japanese).

Papamanoli, E., Kotzekidou, P., Tzanetakis, N. \& LitopoulouTzanetaki, E. (2002). Characterization of Micrococcaceae isolated from dry fermented sausage. Food Microbiol 19, 441-449.

Pathom-aree, W., Stach, J. E. M., Ward, A. C., Horikoshi, K., Bull, A. T. \& Goodfellow, M. (2006). Diversity of actinomycetes isolated from Challenge Deep sediment $(10,898 \mathrm{~m})$ from the Mariana Trench. Extremophiles (in press).

Saitou, N. \& Nei, M. (1987). The neighbor-joining method: a new method for reconstructing phylogenetic trees. Mol Biol Evol 4, 406-425.

Schleifer, K. H. (1985). Analysis of the chemical composition and primary structure of murein. Methods Microbiol 18, 123-156.

Schleifer, K. H. \& Kandler, O. (1972). Peptidoglycan types of bacterial cell walls and their taxonomic implications. Bacteriol Rev 36, 407-477.

Stackebrandt, E. (2003). The family Dermatophilaceae. In The Prokaryotes: an Evolving Electronic Resource for the Microbiological Community, 3rd edn, release 3.15 (December 2003). Edited by M. Dworkin and others. New York: Springer. http://link.springer-ny. com/link/service/books/10125/

Stackebrandt, E. \& Schumann, P. (2000). Description of Bogoriellaceae fam. nov., Dermacoccaceae fam. nov., Rarobacteraceae fam. nov. and Sanguibacteraceae fam. nov. and emendation of some families of the suborder Micrococcineae. Int J Syst Evol Microbiol 50, 1279-1285.

Stackebrandt, E., Koch, C., Gvozdiak, O. \& Schumann, P. (1995). Taxonomic dissection of the genus Micrococcus: Kocuria gen. nov., Nesterenkonia gen. nov., Kytococcus gen. nov., Dermacoccus gen. nov., and Micrococcus Cohn 1872 gen. emend. Int J Syst Bacteriol 45, 682-692.

Sutcliffe, I. C. (2000). Characterisation of a lipomannan lipoglycan from the mycolic acid containing actinomycete Dietzia maris. Antonie van Leeuwenhoek 78, 195-201.

Tamaoka, J. \& Komagata, K. (1984). Determination of DNA base composition by reversed-phase high-performance liquid chromatography. FEMS Microbiol Lett 25, 125-128. 
Uchida, K., Kudo, T., Suzuki, K. I. \& Nakase, T. (1999). A new rapid method of glycolate test by diethyl ether extraction, which is applicable to a small amount of bacterial cells of less than one milligram. J Gen Appl Microbiol 45, 49-56.

Vickers, J. C., Williams, S. T. \& Ross, G. W. (1984). A taxonomic approach to selective isolation of streptomycetes from soil. In Biological, Biochemical and Biomedical Aspects of Actinomycetes, pp. 553-561. Edited by L. Ortiz-Ortiz, L. F. Bojalil \& V. Yakoleff. Orlando: Academic Press.

Wayne, L. G., Brenner, D. J., Colwell, R. R. \& 9 other authors (1987). International Committee on Systematic Bacteriology. Report of the ad hoc committee on reconciliation of approaches to bacterial systematics. Int J Syst Bacteriol 37, 463-464. 